\title{
ESTs analysis in maize developing kernels exposed to single and combined water and heat stresses
}

\author{
Violeta Andjelković; Dragana Ignjatović-Micić* \\ Maize Research Institute Zemun Polje, S. Bajića 1 - 11185 - Belgrade, Serbia. \\ *Corresponding author <idragana@mrizp.rs>
}

\begin{abstract}
Molecular and metabolic response of plants to a combination of two abiotic stresses is unique and cannot be directly extrapolated from the response of plants to each of the stresses individually. cDNA macroarray has become a useful tool to analyze expression profiles and compare the similarities and differences of various expression patterns. A macroarray of approximately 2,500 maize (Zea mays L.) cDNAs was used for transcriptome profiling in response to single and simultaneous application of water and high temperature stress of maize developing kernels at 15 days after pollination. All stress treatments (water stress-WS, heat stress-HS and their combined application-CS) induced changes in expression of 106 transcripts with 54 upregulated and 52 down-regulated. There were 11 up-regulated and 15 down-regulated transcripts in common for all three stresses. Although these common transcripts showed existence of a mutual mechanism in stress response, the 23 transcripts induced only in CS indicate that plants responded in a different manner when exposed to simultaneous effects of both stresses. A glimpse of functions regulated under WS, HS and CS is provided, and also the common and different responses between individual and simultaneous stresses.
\end{abstract}

Key words: abiotic stress, down-regulation, macroarray, up-regulation

\section{Análise de ESTs de espigas de milho em desenvolvimento expostas a estresse simples e combinado de água e calor}

\begin{abstract}
RESUMO: A resposta molecular e metabólica de plantas a uma combinação de dois estresses abióticos é singular, e não pode ser diretamente extrapolada da resposta das plantas a cada um dos estresses individualmente. O macroarranjo do cDNA, tornou-se uma ferramenta útil para analisar os perfís de expressão e comparar as similaridades e diferenças de vários padrões de expressão. Um macroarranjo de 2.500 cDNAs de milho (Zea mays L.) foi usado para traçar um perfil de transcriptoma em resposta ao stress ocasionado por uma única e simultânea aplicação de água e alta temperatura em espigas em desenvolvimento, 15 dias após a polinização. Todos os tratamentos de stress (stress de água - SA, stress de calor - SC e sua aplicação combinada - AC) induziram modificações na expressão de 106 transcritos com 54 regulados acima e 52 regulados abaixo. Houve 11 transcritos regulados acima e 15 regulados abaixo em comum para os três estresses. Embora esses transcritos em comum mostrassem a existência de um mecanismo mútuo na resposta do estresse, os 23 transcritos induzidos somente em AC indicam que as plantas respondem de maneira diferente quando expostos aos efeitos simultâneos de ambos os estresses. Vislumbram-se funções reguladas por SA, SC e AC e também efeitos comuns e diferentes entre estresses individuais e simultâneos.

Palavras-chave: stress abiótico, regulação negativa, macroarranjo, regulação positiva
\end{abstract}

\section{Introduction}

Environmental abiotic stresses have detrimental impact on crop-yield worldwide and among the most important in temperate areas are drought and high temperatures. Drought at flowering and grain-filling induces high grain yield reductions in maize (Praba et al., 2009). Molecular and metabolic responses of plants to a combination of two different abiotic stresses are unique and cannot be directly extrapolated from the stresses individually (Mittler, 2006). Different stresses might require conflicting or antagonistic responses and a combination of drought and heat stress was found to alter plant metabolism in a novel manner compared with single stresses separately (Rizhsky et al., 2004). The stress combination should be regarded as a new state of abiotic stress in plants that requires a new defense or acclimation response (Mittler, 2006).

The complexity and polygenic nature induced by abiotic stress disabled conventional breeding to succeed in efficient and stable improvement of maize drought and heat tolerance. Recently, development of cDNA macroarray and microarray technologies enabled systematic analysis of the expression levels for thousand of genes simultaneously (Shi et al., 2005; Andjelkovic and Thompson, 2006; Zhang et al., 2009), thus contributing to the understanding of basic mechanisms underlying stress tolerance.

We performed comparative expressed sequence tags (ESTs) analysis in response to single and simultaneous application of drought and high temperature for identification of gene expression and affected pathways in developing maize kernels, using macroarray analysis. The aim 
of this profiling was to indicate different and mutual responses in maize kernels to single and combined stresses during grain-filling, as molecular mechanisms of responses to drought at this stage are not fully understood, although maize is frequently exposed to severe stress in field with significant yield loss.

\section{Material and methods}

Maize (Zea mays L.) plants were grown in 10-L pots in greenhouse, under standard conditions with 16-h light period $\left(300 \mu \mathrm{E}^{-2} \mathrm{~s}^{-1}, 21-25^{\circ} \mathrm{C}\right)$ and 8 -h dark period $\left(15^{\circ} \mathrm{C}\right)$. Plants were grown on soil mix (soil : vermiculite $=3: 2$ ), irrigated daily and fertilized once a week. Self-pollinated ears were harvested at 15 days after pollination (DAP).

Stresses treatments were performed on plants at $5 \mathrm{DAP}$. Plants were subjected to water stress (WS) by completely withdrawing water until harvesting. Heat stress (HS) was applied by exposing the plants to $35^{\circ} \mathrm{C} / 25^{\circ} \mathrm{C}$ day/night cycle for $16 / 8-\mathrm{h}$, with relative humidity maintained at $60 \%$. Combination of heat and water stress (CS) was performed by simultaneously subjecting plants to HS and WS, under conditions already described. Control plants were grown under defined standard greenhouse conditions $\left(21-25^{\circ} \mathrm{C} / 15^{\circ} \mathrm{C}\right.$ day/night cycle for $\left.16 / 8-h\right)$. Leaf water status was determined by relative water content (RWC), measured on the control and stressed plants. After three days of withholding water (8 DAP) visible signs of stress such as leaf rolling and leaf blade coloration appeared on the lower part of the plants. Leaf samples were colleted between 12 a.m. and 1 p.m. at 0,3 and 10 days after stress application and RWC was calculated as follows: RWC= fresh weight - dry weight) / (turgid weight - dry weight)*100 (Barr and Weatherley, 1962). The kernels of all plants, i.e. stressed and controlled, were collected at 15 DAP. All experiments were performed in triplicates and repeated three times. Pooled samples for each treatment were frozen in liquid nitrogen and stored at $-80^{\circ} \mathrm{C}$. Total RNA was extracted using Perfect RNA ${ }^{\text {tm }}$ kit (Eppendorf Scientific, Inc. Hamburg, Germany) and prepared for macroarray probes.

Filter arrays were produced with $\sim 2500$ ESTs from unstressed maize tissues (mostly leaf and endosperm). Inserts were PCR amplified and the PCR products were separated by electrophoresis on agarose gels to confirm amplification quality and quantity and spotted onto the membrane using a robotic spotting device (BioGrid robot Biorobotics, UK).

Reproducibility of the experiment was achieved by arraying each cDNA clone twice per array and by repeating the same experiment four times. To check the sensitivity of the detection system, genes uidA and a ribosomal cistron (pTA71) were used as internal controls. pBluescript plasmid probe was used to assess hybridization to the cloning vector and cDNA clones encoding human nebulin and desmin, which have no homology in maize, were employed as negative controls. For some of the so-called housekeeping genes, expression levels varied with different experimental treat- ments, but for the gene p'TA71, as confirmed by Northern blot, expression was invariant. Normalization of each filter was performed by using the mean signal intensity of nebulin as a non-plant control (Desprez et al., 1998). Arrays were prepared on $22.2 \mathrm{~cm}^{2}$ (six field areas of $8 \mathrm{~cm}^{2} \times 12 \mathrm{~cm}^{2}$ ) nylon membranes (Hybond $\mathrm{N}+$, Amersham), which were pre-wetted under denaturing conditions $\left(1.5 \mathrm{~mol} \mathrm{~L}^{-1} \mathrm{NaCl} ; 0.5 \mathrm{~mol}\right.$ $\mathrm{L}^{-1} \mathrm{NaOH}$ ). The BioGrid robot (Biorobotics, UK) produced DNA spots in duplicates in a $4 \times 4$ pattern. After spotting, filters were neutralized $\left(1 \mathrm{~mol} \mathrm{~L}^{-1}\right.$ Tris $\mathrm{pH} 7.6 ; 1.5 \mathrm{~mol} \mathrm{~L}^{-1}$ $\mathrm{NaCl})$ and DNA was fixed to the membrane by UV radiation at $120,000 \mu \mathrm{J} \mathrm{cm}^{-2}$ for $30 \mathrm{~min}$ using Stratalinker (Stratagene, Netherlands).

Total RNA prepared from kernels of stressed and control samples were reverse-transcribed and used as probes for expression profile analysis. The reverse transcription reaction was performed at $43^{\circ} \mathrm{C}$ for $1 \mathrm{~h}$, in a $30 \mu \mathrm{L}$ reaction volume containing $5 \times$ Superscript buffer (GibcoBRL), $0.01 \mathrm{~mol} \mathrm{~L}^{-1} \mathrm{M}$ DTT, $1 \mathrm{mmol} \mathrm{L}{ }^{-1} \mathrm{dNTP} \operatorname{mix}$ [dATP, dGTP, dTTP], $5 \mu \mathrm{mol} \mathrm{L}{ }^{-1}$ dCTP, $\left[\alpha^{33} \mathrm{P}\right]$ dCTP 3 $\mu \mathrm{Ci}$ and $200 \mathrm{U}$ of Superscript RT. Membranes were prehybridized in $20 \mathrm{~mL}$ of Church buffer $\left(0.5 \mathrm{~mol} \mathrm{~L}^{-1}\right.$ $\mathrm{Na}_{2} \mathrm{HPO}_{4} \mathrm{pH} 7.2,7 \%$ SDS, $1 \mathrm{mmol} \mathrm{L}{ }^{-1}$ EDTA), including $200 \mu \mathrm{L}$ of denaturated salmon sperm DNA $(10 \mathrm{mg}$ $\left.\mathrm{mL}^{-1}\right)$, at $65^{\circ} \mathrm{C}$ for $2 \mathrm{~h}$. The probes were denaturated by boiling for $5 \mathrm{~min}$, followed by $5 \mathrm{~min}$ on ice. After prehybridization the denaturated probes were added to the buffer and hybridization was carried on overnight (at least $10 \mathrm{~h}$ ) at $65^{\circ} \mathrm{C}$. Following hybridization the membranes were washed twice for $30 \mathrm{~min}$ at $65^{\circ} \mathrm{C}$ in washing buffer (40 $\mathrm{mmol} \mathrm{L}^{-1} \mathrm{Na} 2 \mathrm{HPO} 4, \mathrm{pH} 7.2$ and $0.1 \%$ SDS). Subsequently, the filters were exposed to a phosphor screen overnight and scanned using ImageQuant software and Storm PhosphorImager (Molecular Dynamics).

The image analysis, quantification of signal intensities and first normalization by the average signal of all spots were done using the Array Vision 5.0 software (Imaging Research, Canada). Statistical analysis of the data obtained was performed in two steps by Array Stat software (Imaging Research, Canada): i) we chose 'Automatic model selection for independent conditions' with minimum two (of four) valid observations required. It performed offset corrections by normalization across replicates. Outliers were detected and removed automatically prior to further analysis. ii) normalization across conditions was performed by 'Mean of reference values' (human nebulin). Reported output colored in blue data from genes exhibited different expression levels. Genes with changes in expression compared to control were identified as up- or down-regulated. Threshold of 2 is widely applied in distinguishing affected genes, even though it can still lead to some misclassification of genes (Deyholos and Galbraith, 2000). Herein, only genes with more than 2-fold change in expression are presented. BLASTN and BLASTX similarity searches against the non-reduntant NCBI protein database were performed and annotations were assigned to each query. Annotation and tentative contigs (TCs) were identified according to The Gene Index Database (http:// compbio.dfci.harvard.edu/). 
Expression profiles of stress-inducible cDNAs were also analyzed by the hierarchical clustering in the Gene Cluster software (http://bonsai.ims.u-tokyo.ac.jp/ mdehoon/ software / cluster).

Isolated RNA from stressed and control plants was also used for RNA gel-blot analysis. Total RNA $(10 \mu \mathrm{g})$ was separated by electrophoresis in denaturating formaldehyde $1 \%$ agarose gel and then capillary transferred to Hybond $\mathrm{N}^{+}$membrane. Selected probes were labeled with $\left[{ }^{32} \mathrm{P}\right]$ dCTP using RediPrime DNA labeling system (Amersham). Hybridization was performed in hybridization buffer containing $5 \mathrm{x}$ SSC, $5 \mathrm{x}$ Denhardts, $50 \%$ formamide, $1 \%$ SDS and $100 \mu \mathrm{g} \mu \mathrm{L}^{-1}$ salmon sperm DNA, overnight at $42^{\circ} \mathrm{C}$. Filters were then washed twice, in $2 \mathrm{x}$ SS, $0.1 \%$ SDS and in $0.2 \mathrm{xSC}, 0.1 \% \mathrm{SDS}$, for $5 \mathrm{~min}$ at room temperature. Another washing was done in $0.2 \mathrm{x}$ SSC, $0.1 \%$ SDS for $15 \mathrm{~min}$ at $42^{\circ} \mathrm{C}$. Scanning was performed as described above. Each filter was stripped and re-hybridized with RNA probe pTA71 as a loading control.

\section{Results and Discussion}

To ensure that plants were grown under the required stress conditions RWC was monitored through the experiment. The reduction in RWC occurred at 3 day and at 10 day it was decreased by $13 \%$ in heat stress, $31 \%$ in water stress and $45 \%$ in combined stress in comparison with control plants. The greatest decrease in RWC was observed with the combined stress (Figure 1). Similar results were presented in maize (Hui-Yong et al., 2007) and wheat (Sharma and Kaur, 2009).

All three stress treatments (combined stress - CS, water stress - WS and heat stress - HS) induced changes in expression of 106 (4.3\% of all analyzed) transcripts and $54(2.2 \%)$ were up-regulated. There were 11 up-regulated transcripts in common for HS, WS and CS, seven for WS and CS, seven for HS and CS, one for WS and HS. Considering significantly up-regulated transcripts for each distinct stress treatment, there were 23 transcripts identified for CS, one for WS and four for HS (Figure 2). Detailed assessments on

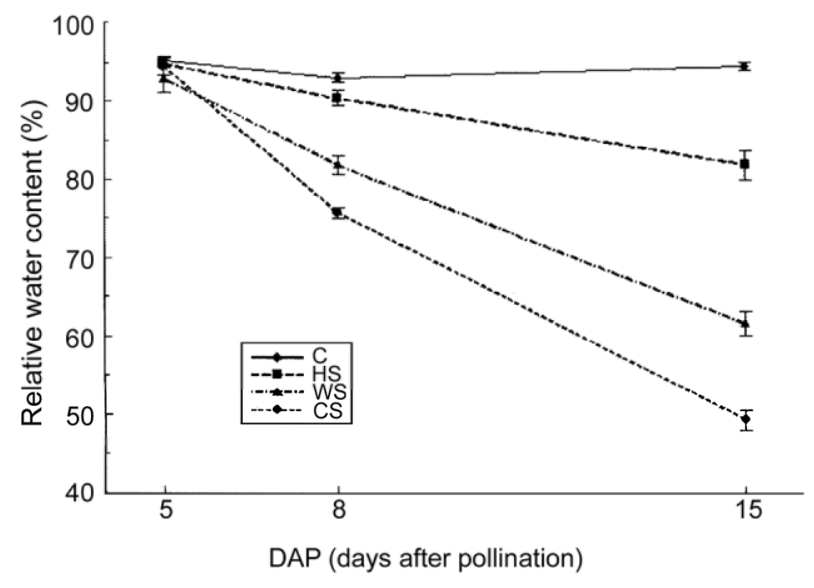

Figure 1 - Changes of leaf relative water content (RWC) in maize leaves under stress treatments at days 5, 8 and 15 DAP. C-control, HS-heat stress, WS-water stress and CS-combined stress. Data shown are means \pm SE of three replicates. the expression ratios of all up-regulated maize ESTs are given in Table 1. Up-regulated transcripts include only ESTs with homology to previously identified or putative genes in Z. mays (24), O. sativa (18), H. vulgare (four), $A$. thaliana (five) and three share homology to other plants. A total of 54 up-regulated genes during the stress treatments were grouped into functional categories based on the categorization developed by the Gene Ontology (GO) Consortium (www.geneontology.org). With regard to biological process (Table 1), transcripts were assigned to nine groups (Table 1), including photosynthesis (three), transport (six), stress (19), cytoskeleton (three), metabolism (11), cell cycle (three), translation (two) and protein formation (one). The other six ESTs were assigned to the unclassified or unknown proteins category. Molecular function of the up-regulated ESTs was identified for 42 transcripts, while for $13(23.6 \%)$ transcripts it could not be determined (Figure 3). Most of the transcripts are involved in protein binding (13 transcripts). For seven transcripts (grouped as other) following molecular functions were identified: lipid binding, oxygen binding, peptide binding, rRNA binding and translation initiation factor activity.

Here we focus on a set of up-regulated transcripts as less attention has been paid to down-regulation in expression studies. However, for an insight into a global answer to stress response, we analyzed down-regulated ESTs grouped together by cluster analysis (Figure 4). Detailed assessments on the expression ratios of down-regulated maize ESTs are given in Table 2. Down-regulated transcripts include only ESTs with homology to previously identified or putative genes. Ten out of 17 identified down-regulated transcripts are with homology to previously identified or putative genes in Z. mays, four to $O$. sativa, two to $A$. thaliana and one to $H$. vulgare. With regard to biological process, transcripts were assigned to six groups (Table 2), including photosynthesis

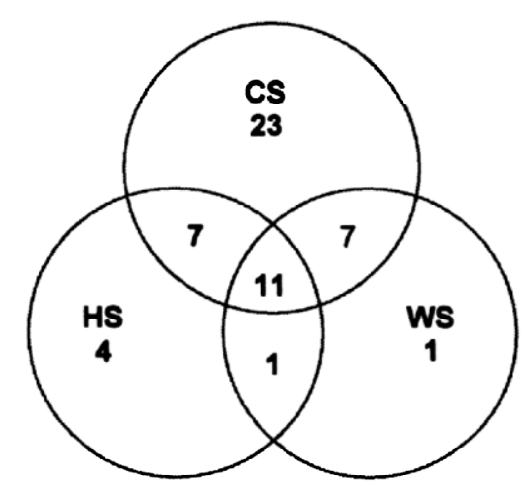

Figure 2 - Venn diagram of up-regulated transcripts (expression ratio stressed/control $>2$ fold) in maize developing kernels in response to the applied stresses: heat stress (HS), water stress (WS) and combination of heat and water stress (CS). Numbers in the circle overlap indicate the number of transcripts common to the compared stresses and numbers outside the overlap indicate the number of transcripts exclusive to the particular stress. 
Table 1 - List of significantly up-regulated ESTs in response to water (WS), heat (HS) and/or combined (CS) stress treatments in developing maize kernels.

\begin{tabular}{|c|c|c|c|c|c|}
\hline \multirow{2}{*}{$\begin{array}{l}\text { Tentative contig } \\
\text { (TC) }\end{array}$} & \multirow{2}{*}{ Annotation } & \multicolumn{3}{|c|}{ Expression ratio } & \multirow{2}{*}{$\begin{array}{l}\text { Biological } \\
\text { function }\end{array}$} \\
\hline & & WS/Control & 1 HS/Control & CS/Control & \\
\hline \multicolumn{6}{|l|}{ In HS and CS } \\
\hline TC506584 & auxin-induced protein (O. sativa) & & 12.7 & 7.2 & other \\
\hline TC 468236 & ATP synthase ( $Z$.mays) & & 2.3 & 4.3 & transport \\
\hline TC 464003 & vacuolar ATPase B subunit (H.vulgare) & & 3.9 & 3.8 & transport \\
\hline TC 487563 & catalase isozy me 3 (Z. mays) & & 2.5 & 3.2 & stress \\
\hline TC 467312 & heat shock protein 81 (O. sativa) & & 3.4 & 2.8 & stress \\
\hline TC463096 & pathogenesis-related protein (Z. mays) & & 2.2 & 2.9 & stress \\
\hline TC458346 & ABA-responsive element- (ABRE) (Z. mays) & & 2.7 & 2.9 & stress \\
\hline \multicolumn{6}{|l|}{ In CS only } \\
\hline TC542593 & male sterility protein 2 (A. thaliana) & & & 4.5 & unknown \\
\hline TC 481964 & alpha-6 tubulin (Z. mays) & & & 4.5 & cy tosk eleton \\
\hline TC 467824 & alpha-3 tubulin ( $Z$.mays) & & & 4.5 & cy toskeleton \\
\hline TC 505652 & fatty acyl coA reductase $(O$ sativa) & & & 4.5 & metabolism \\
\hline TC289703 & cy tochrome $\mathrm{P} 450$ monooxy genase (O. sativa) & & & 3.6 & transport \\
\hline TC 479478 & $\begin{array}{l}\text { cy tosolic gly ceroldehy de-3-phosphate } \\
\text { dehy drogenase (Z. mays) }\end{array}$ & & & 3.4 & stress \\
\hline TC525318 & alpha-1 tubulin (Z. mays) & & & 3.3 & cy toskeleton \\
\hline TC 462753 & cell division protein (Z. mays) & & & 3.3 & cell cycle \\
\hline $\mathrm{TC} 4460$ & chlorophyll a /b-binding protein (H. vulgare) & & & 3.1 & photosy nthesis \\
\hline TC 458293 & glucose-6-phosphate (O. sativa) & & & 3.1 & metabolism \\
\hline TC 464688 & eucary otic translation initiation factor 5 (Z. mays) & & & 2.9 & translation \\
\hline TC 458802 & translation initiation factor (Z. mays) & & & 2.9 & translation \\
\hline TC286854 & phospholipid cy tidy ly ltransferase (O. sativa) & & & 2.8 & metabolism \\
\hline TC 483484 & heat shock protein $81($ O. sativa $)$ & & & 2.7 & stress \\
\hline TC 474466 & cycloartenol sy nthase (O. sativa) & & & 2.6 & metabolism \\
\hline TC 302534 & cell wall gly coprotein (A. thaliana) & & & 2.5 & other \\
\hline TC 458415 & phy toene sy nthase (Z. mays) & & & 2.4 & metabolism \\
\hline TC546852 & poly ubiquitin ( $T$. caerulescens) & & & 2.3 & metabolism \\
\hline TC441536 & cyclophilin (O. sativa) & & & 2.3 & $\begin{array}{l}\text { protein } \\
\text { formation }\end{array}$ \\
\hline TC 458487 & superoxide dismutase (Z. mays) & & & 2.2 & stress \\
\hline TC290568 & $\begin{array}{l}\text { ADP-glucose py rophosphory lase small subunit }(O . \\
\text { sativa) }\end{array}$ & & & 2.1 & metabolism \\
\hline TC 487801 & glucose-1-phosphate adeny ly ltransferase (Z. mays) & & & 2.0 & metabolism \\
\hline TC468456 & d-UDP-glucose dehy dratase (O. sativa) & & & 2.0 & metabolism \\
\hline \multicolumn{6}{|l|}{ In WS and $H S$} \\
\hline TC 467940 & non-specific lipid-transfer protein (Z. mays) & 3.5 & 6.5 & & transport \\
\hline \multicolumn{6}{|l|}{ In WS only } \\
\hline TC 494687 & 60S ribosomal protein (O. sativa) & 2.1 & & & cell cycle \\
\hline \multicolumn{6}{|l|}{ In HS only } \\
\hline TC 458178 & disease resistance protein (Z. mays) & & 2.3 & & stress \\
\hline TC 300734 & chilling-inducible protein (O. sativa) & & 2.2 & & stress \\
\hline TC 499474 & $\begin{array}{l}\text { glycine-rich RNA-binding, ABA inducible protein } \\
\text { (Z. mays) }\end{array}$ & & 2.2 & & stress \\
\hline TC 464194 & actin-depoly merizing factor 3 (Z. mays) & & 2.0 & & stress \\
\hline
\end{tabular}

TCs and annotations according to The Gene Index Database (www.compbio.dfci.harvard.edu). Functional categories based on the categorization developed by the Gene Ontology (GO) Consortium (www.geneontology.org) 
(three), transport (three), stress (three), metabolism (four), cell cycle (one) and translation (one). The other two ESTs were assigned to the unknown proteins category. No downregulated transcripts were identified only in CS (data not presented). This could probably be due the fact that ESTs used in our profiling were obtained from unstressed maize tissues. Thus, it could be presumed that the overall transcripts' expression would probably be higher if macroarray was performed using library constructed from stressed tissues.

Eleven up-regulated transcripts were in common for all three stress treatments. (F-test, $p$-value 0.05, and Step-down Bonferroni as a multiple test correction method).These transcripts had the highest expression ratios among all the increased ESTs. Two of these transcripts (thaumatin-like protein and glycine-rich protein) were by far the most induced transcripts, highly above three times the threshold in all three stresses. Thaumatin-like protein belongs to pathogenesis-related proteins. Similar to other pathogenesis-related proteins, thaumatin-like protein synthesis can occur under general stress conditions and may be constitutively present in response to environmental or physiological stimuli (Zamani et al., 2004). Gene expression of glycine-rich proteins (GRP) can be modulated by various environmental stimuli, including wounding, pathogens, osmotic stresses, cold, light, hormones and circadian rhythm (Sachetto-Martins et al., 2000). The diverse response of GRPs to various environmental and developmental signals suggests that these proteins may play different but important roles in the maintenance of plant function and in adaptation to stress. Some plant glycine-rich proteins possess nucleic acid binding ability and are involved in gene expression regulation (Kim et al., 2007; Cai et al., 2008).

All the other transcripts belonging to this group were more expressed in CS compared to WS and HS. This difference is mostly pronounced for metallothionein and prolinerich protein. Metallothioneins function in plant protection and up-regulation in response to different stresses were confirmed in the other macroarray studies of Reymond et al. (2000) and Kawasaki et al. (2001). They play important roles in metal homeostasis and detoxification because of their ability to bind different heavy metal ions (Vasak and Hasler, 2000). Although there has been no report to indicate DNAbinding activity of a metallothionein protein, their nuclear localization in various cellular events has been reported, which has led to the hypothesis that the metallothionein mediates gene expression by donating zinc, directly or indirectly, to transcription factors (Butcher et al., 2004; Cai et al., 2008). Regulatory studies indicate that proline-rich proteins (PRP), have a structural role in the cell wall, as well as a storage or defense function (Jose-Estanyol et al., 1992). In addition, wounding, endogenous elicitors, funga1 elicitor, ethylene, cell culturing, and light can affect PRP gene expression (Sheng et al., 1991). Proline-rich proteins were shown to be up-regulated during water-deficit in $A$. thaliana (Bray, 2002).

Two of three up-regulated transcripts encoding components of the photosynthesis pathways were identified in all three stress treatments. Transcripts involved in photosynthe-

Table 2 - List of significantly down-regulated ESTs in response to water (WS), heat (HS) and combined (CS) stress treatments in developing maize kernels.

\begin{tabular}{|c|c|c|c|c|c|}
\hline \multirow{2}{*}{$\begin{array}{l}\text { Tentative } \\
\text { contig (TC) }\end{array}$} & \multirow{2}{*}{ Annotation } & \multicolumn{3}{|c|}{ Expression ratio } & \multirow{2}{*}{$\begin{array}{l}\text { Biological } \\
\text { function }\end{array}$} \\
\hline & & WS/Control & HS/Control & CS/Control & \\
\hline TC470272 & abscisic acid- and stress-induced protein (O. sativa) & -19.3 & -5.5 & -5.2 & stress \\
\hline TC349303 & malate dehydrogenase (NADP+) (Z. mays) & -13.5 & -6.5 & -4.4 & metabolism \\
\hline TC458526 & interacting-zinc finger protein 1 (Z. mays) & -11.1 & -5.8 & -3.4 & transport \\
\hline TC 495400 & photosy stem I PSI-K subunit (H. vulgare) & -10.4 & -5.3 & -3.0 & photosynthesis \\
\hline TC526421 & phosphatidy linositol transfer protein(O. sativa) & -10.3 & -1.0 & -7.6 & transport \\
\hline TC 475504 & legumin-like protein (Z. mays) & -6.9 & -2.7 & -6.9 & unknown \\
\hline TC 468236 & ATP sy nthase gamma chain chloroplast (Z. mays) & -5.9 & -3.5 & -5.3 & photosynthesis \\
\hline TC506023 & BETL2 protein (Z. mays) & -6.3 & -3.0 & -4.9 & stress \\
\hline ТC 464507 & $\begin{array}{l}\text { CCAAT-binding transcription factor subunit A }(O \text {. } \\
\text { sativa) }\end{array}$ & -4.7 & -4.2 & -4.4 & cell cycle \\
\hline TC345125 & phosphoprotein phosphatase (O. sativa) & -4.6 & -5.1 & -2.3 & metabolism \\
\hline TC 468023 & early nodulin (A. thaliana) & -4.0 & -4.7 & -3.2 & transport \\
\hline TC503833 & $19 \mathrm{kD}$ zein protein (Z. mays) & -4.1 & -3.0 & -4.3 & metabolism \\
\hline TC333458 & nitrilase-associated protein (A. thaliana) & -4.0 & -5.9 & -2.7 & unknown \\
\hline TC564432 & chloroplast membrane (Z. mays) & -3.5 & -3.8 & -2.7 & stress \\
\hline TC522429 & chlorophyll a/b-binding preprotein (Z. mays) & -2.7 & -2.1 & -5.3 & photosynthesis \\
\hline TC 470704 & $60 S$ acidic ribosomal protein $(Z$. mays $)$ & -1.6 & -7.4 & -1.0 & translation \\
\hline TC 481030 & starch branching enzy me $\Pi$ Ilb $(Z$. mays $)$ & -1.7 & -2.8 & -2.0 & metabolism \\
\hline
\end{tabular}

TCs and annotations according to The Gene Index Database (www.compbio.dfci.harvard.edu). Functional categories based on the categorization developed by the Gene Ontology (GO) Consortium (www.geneontology.org). 


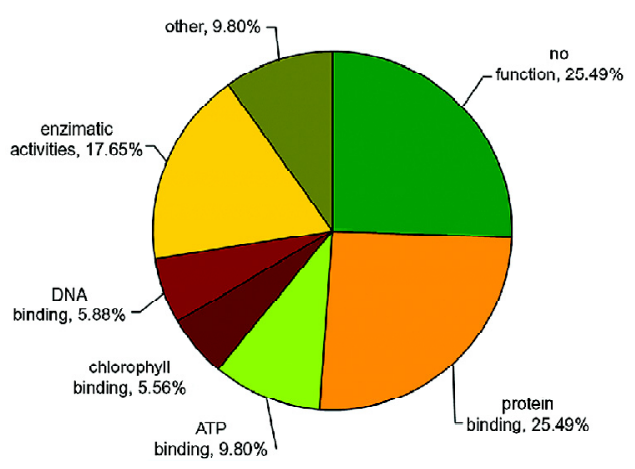

Figure 3 - Molecular function of stress induced transcripts. A total of 54 up-regulated genes during stress treatment were grouped based on the categorization developed by the Gene Ontology (GO) Consortium (www.geneontology.org). Each category was given a percentage of all induced genes.

sis were up-regulated in nonphotosynthetic organs in response to stress (Wang et al., 2003; Zhuang et al., 2008). This was explained by the hypothesis that they were involved in the control of redox state under water stress (Grossman et al., 2001). Cytochrome $\mathrm{P}_{450}$ monooxygenase and plastocyanin are known to be involved in electron transport processes and have a role in the control of redox state. They were approximately two fold increased in CS compared to WS and HS. Cytochrome $\mathrm{P}_{450}$ monooxygenase mediates the biosynthesis of lignins, terpenes, alkaloids and the variety of secondary metabolites, which act in plant defense and oxidative detoxification (Persans et al., 2001). Up-regulation of cytochrome $\mathrm{P}_{450}$ monooxygenase was detected in drought stress in barley (Ozturk et al., 2002) and aluminium stress in $A$. thaliana (Goodwin and Sutter, 2009). Plastocyanin up-regulation was identified under water and salt stress of developing maize kernels (Andjelkovic and Thompson, 2006).

Cytosolic glyceraldehyde 3 phosphate dehydrogenase, which is up-regulated under all three stress treatments, was also up-regulated in leaves and roots of maize seedlings in response to polyethylenglicol stress (Zheng et al., 2004). Suppression of genes encoding glyceraldehyde-3-phosphate dehydrogenase and other enzymes related to glucose-phosphate metabolism has been noted in response to dehydration shock treatment in barley (Talame et al., 2007) and drought stress in tolerant maize landraces (Hayano-Kanashiro et al., 2009).

Alpha-ketoglutarate dehydrogenase and protein kinase activity transcripts were the least induced in CS among all eleven transcripts. The function of alpha-ketoglutarate dehydrogenase could not be established according to the categorization developed by the Gene Ontology (GO) Consortium. Rhizky et al. (2004) showed that transcripts encoding signal transduction, including protein kinases, were elevated during a combination of drought and heat stress in $A$. thaliana and $\mathrm{Yu}$ and Setter (2003) showed that a calcium dependent protein kinase was up-regulated in both maize endosperm and placenta.

Apart from the common ESTs for all three stress treatments, 24 transcripts were up-regulated only in CS. These

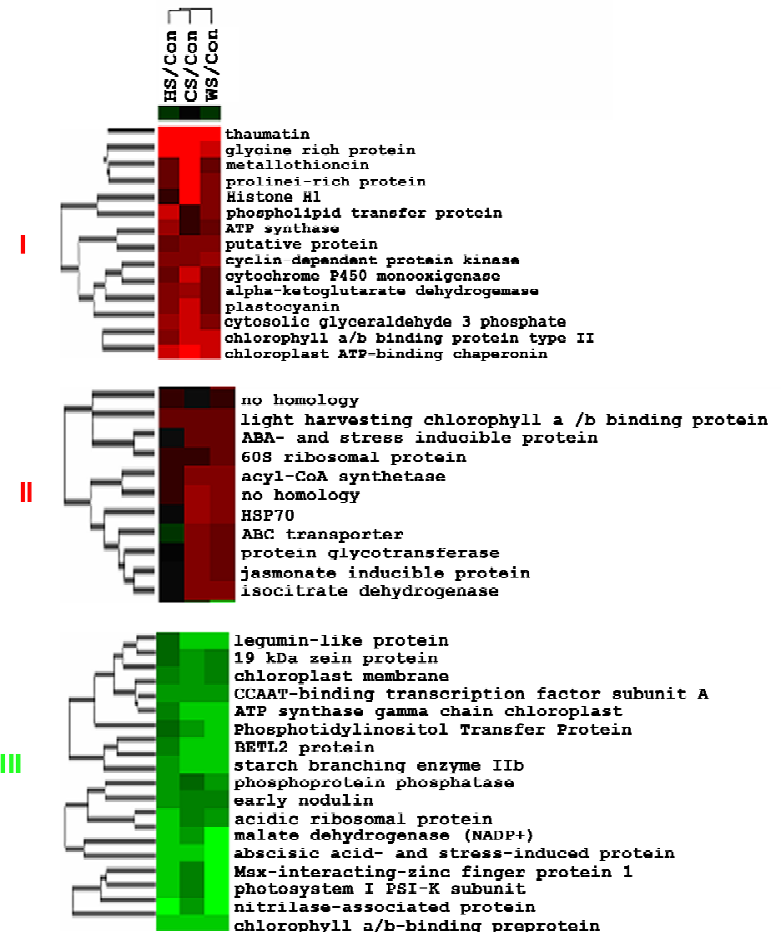

Figure 4 - Expression profiles of maize kernel transcripts subjected to heat stress (HS), combined stress (CS) and water stress (WS). Ratio treatment/control was $\log _{2}$ transformed and subjected to hierarchical clustering. Up-regulation (or suppression) ranges from black (no expression changes) to saturated red (up-regulation) and green (down-regulation). Three groups with distinct expression patterns were created - group I with 15 genes remarkably expressed at least under two stress treatments; group II with 11 genes with expression ratios stress/ control slightly above 2 and group III with 17 genes down-regulated in response to all applied stresses.

specifically induced transcripts are involved in stress response, metabolism, photosynthesis, translation, as well as protein and cytoskeleton formation. The expression ratios were in the range from 2.0 to 4.5 , in general considerably lower than expression ratios of common transcripts induced in all three stresses. These results confirm that stress combination should be regarded as a new state of abiotic stress in plants.

As the same ESTs library was used in the previous experiments (Andjelkovic and Thompson, 2006), in which developing kernels were analyzed under water and salinity stress treatments, the results from both studies were compared. In the previous study the stress was applied in the form of a shock treatment - stalks of maize plants were cut $10 \mathrm{~cm}$ below and above the ear and placed on filter paper (drought stress), i.e. submerged in liquid medium (salt stress) for three days, until sampling. Four common up-regulated transcripts with high expression ratios were identified in both studies for all stresses applied. These are glycine rich protein, metallothionein, plastocyanin and cytosolic glyceraldehyde 3 phosphate. Another six common up-regulated transcripts were 
identified in the salt and CS (alpha-6 tubulin, alpha-3 tubulin, cycloartenol synthase, phytoene synthase, male sterility protein, eukaryotic translation initiation factor 5). However, the shock treatment is not comparable to field situation, and for this reason in the present study we performed HS, WS and CS with stress conditions more similar to natural conditions.

Drought triggers the production of abscisic acid (ABA) which induces expression of stress-related genes. Some genes are up-regulated and others down-regulated resulting in overall synthesis of genomic products which may play a role in plant survival under different environmental conditions. In our study the highest suppression was detected for abscisic acid $(\mathrm{ABA}) /$ stress-induced protein in all stress treatments, while Guo et al. (2009) detected its up-regulation in response to 3-days of drought stress in barley. ABA also causes stomatal closure and consequently the inhibition of photosynthesis. In this respect, transcript level of photosynthesis-associated genes for photosystem I PSI-K subunit, ATP synthase gamma chain chloroplast and chlorophyll a/b-binding preprotein decreased during applied WS, HS and CS treatments. Sugar metabolism is closely related to photosynthesis and is also affected by stress stimuli (Hayano-Kanashiro et al., 2009). Although three transcripts involved in sugar metabolism were slightly induced only in CS, their expression ratios were at the threshold level (Table 1). Also, suppression of malate dehydrogenase, an enzyme involved in gluconeogenesis, was detected under all three stress treatments, coinciding with results obtained for barley (Ozturk et al., 2002). Inhibition of genes associated with starch biosynthetic pathway was detected during shade stress in maize (Zinselmeier et al., 2002) and in our experiments starch branching enzyme IIb transcript level was significantly decreased only under heat strees.

Legumin-like proteins and zeins are seed storage proteins usually found in seed endosperm. In our study, leguminlike protein and $19 \mathrm{kD}$ zein transcripts were suppressed in response to all applied stresses, but in roots of maize seedlings, legumin-like proteins were up-regulated in response to water stress (Zhu et al., 2007). Zeins are particularly sensitive to high temperature and it was found that their concentration in response to this stress was reduced during early developmental of maize kernel under heat stress (Monjardino et al., 2005).

Translation factor proteins, like ribosomal proteins, can be differentially expressed under abiotic stress conditions. In our study, 60S acidic ribosomal protein was suppressed only in response to heat stress. (z-test, $p<0.05$ ). Ozturk et al. (2002) found that ribosomal proteins were induced in saltstressed leaves of barley $24 \mathrm{~h}$ after stress application, but suppressed or without expression after shorter exposure $(6 \mathrm{~h}$ and $10 \mathrm{~h}$ ) to the stress.

Hayano-Kanashiro et al. (2009) found that a number of transcription factors were differentially expressed in response to drought stress and after recovery, depending upon maize landraces susceptibility. Members of zinc finger protein and CCAAT-binding transcription factor subunit A were among them, and these transcripts were strongly suppressed under all three stresses applied in our experiment.
To further evaluate these results, a hierarchical clustering analysis of the expression profiles of genes induced by HS, WS and CS was performed (Figure 4). Hierarchical clustering analysis was in agreement with the macroarray expression profiles. Tree groups with distinct expression patterns were created based on the results of cluster analysis. In group I there are 15 genes remarkably expressed at least under two stress treatments. Group II encompasses 11 genes with expression ratios stress/control slightly above 2 . Clustering put together 17 genes in the group III with down-regulation in response to all applied stresses.

To evaluate the validity of the cDNA macroarray study RNA gel-blot analysis was performed. The RNA obtained from stress treatments was examined for a number of ESTs. In general, the results of RNA gel-blot were consistent with the expression data obtained by macroarray analysis. As an illustration, gel blot analysis for metallothionein clone 5C05E10 is presented in Figure 5. A ATP-dependent Clp protease ATP-binding subunit EST was chosen as an example of a transcript that did not change in abundance according to the macroarray data during the applied stress treatments (neutral control). For this transcript both techniques confirm no changes under our experimental conditions.

\section{Conclusion}

Combined effects of water and heat stresses, compared to single stress effects, alter plant response in a novel manner and can be regarded as a new state of abiotic stress that requires a new defense or acclimation response. The role and importance of both identified up and down regulated transcripts is hard to judge from the limited selection of ESTs $(\sim 2500)$.

a)

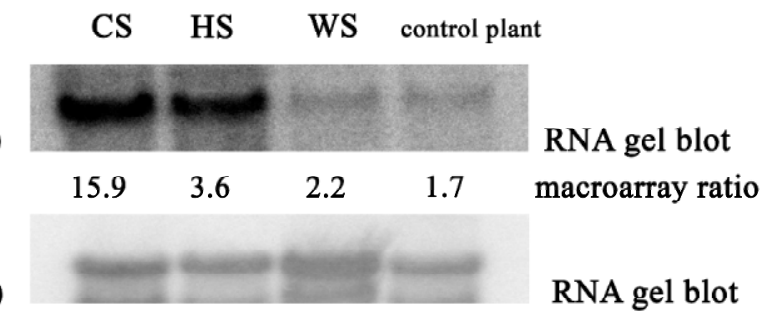

c)

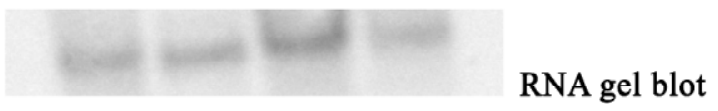

Figure 5 - RNA gel blot analysis and corresponding cDNA macroarray data. a) Verification of macroarray results by RNA gel blot analysis for clone 5C05E10 (metallothionein) in stress conditions: CScombined stress, HS - heat stress WS - water stress. The gene expression ratios from the macroarray are shown under the corresponding RNA blot. b) PTA71 was used as loading control. c) Clone 5C02D08 (ATP-dependent Clp protease ATPbinding subunit) was used as neutral control - a transcript that did not change in abundance according to the macroarray data during the applied stress treatments. 


\section{Acknowledgement}

To Dr. Richard Thompson, Max-Planck-Gesellschaft, Maize Research Institute and Serbian Ministry of Science for support in realization of this project.

\section{References}

Andjelkovic, V.; Thompson, R. 2006. Changes in gene expression in maize kernel in response to water and salt stress. Plant Cell Reports 25: 71-79.

Barr, H.D.; Weatherley, P.E. 1962. A re-exemination of the relative turgidity technique for estimating water deficit in leaves. Australian Journal of Biological Science 15: 413-428.

Bray, E.A. 2002. Abscisic acid regulation of gene expression during water-deficit stress in the era of the Arabidopsis genome. Plant, Cell and Environment 25: 163-161.

Butcher, H.L.; Kennette, W.A.; Collins, O.; Zalups, R.K.; Koropatnick, J. 2004. Metallothionein mediates the level and activity of nuclear factor $\mathrm{jB}$ in murine fibroblasts. Journal of Pharmacology and Experimental Therapeutics 310: 589-598.

Cai, M.; Yuan, T.; Duan, L.; Li, X.; Wang, S. 2008. Identification of potential protein regulators bound to the tissue-specific positive and negative cis-acting elements of a green tissue-specific promoter in rice. Plant Biology 10: 771-777.

Desprez, T.; Amselem, J.; Caboche, M.; Hofte, H. 1998. Differential gene expression in Arabidopsis monitored using cDNA arrays. The Plant Journal 14: 643-652.

Deyholos, M.K.; Galbraith D.W. 2000. High-density microarrays for gene expression analysis. Cytometry 43: 229-238.

Goodwin, S.B.; Sutter T.R. 2009. Microarray analysis of Arabidopsis genome response to aluminium stress. Biologia Plantarum 53: 85-99.

Grossman, A.R.; Bhaya, D.; He, Q. 2001. Tracking the light environment by cyanobacteria and the dynamic nature of light harvesting. Journal of Biological Chemistry 276: 11449-11452.

Guo, P.; Baum, M.; Grando, S.; Ceccarelli, S.; Bai, G.; Li, R.; Korff, M.; Varshney, R. K.; Graner, A.; Valkoun, J. 2009. Differentially expressed genes between drought-tolerant and drought-sensitive barley genotypes in response to drought stress during the reproductive stage. Journal of Experimental Botany 60: 3531-3544.

Hayano-Kanashiro, C.; Calderon-Vasquez, C.; Ibarra-Laciette, E.; HerreraEstrela, L.; Simpson, J. 2009. Analysis of gene expression and physiological responses in three Mexican maize landraces under drought stress and recovery irrigation. PLoS ONE 4: 1-19.

Jose-Estanyol, M.; Ruiz-Avila, L.; Puigdomhnech, P. 1992. A maize embryo-specific gene encodes a proline-rich and hydrophobic protein. Plant Cell 4: 413-423.

Kawasaki, S.; Borchert, C.; Deyholos, M.; Wang, H.; Brazille, S.; Kaxai, K.; Galbraith D.; Bohnert, H. J. 2001. Gene expression profiles during the initial phase of salt stress in rice. The Plant Cell 13: 889-905.

Kim, J.S.; Park, S.J.; Kwak, K.J.; Kim, Y.O.; Kim, J.Y.; Song, J.; Jang, B.; Jung, C.H.; Kang, H. 2007. Cold shock domain proteins and glycinerich RNA-binding proteins from Arabidopsis thaliana can promote the cold adaptation process in Escherichia coli. Nucleic Acids Research 35: 506-516.

Hui-Yong, L.; Huang, S.; Shi, Y.; Song, Y.; Zhao, J.; Wang, F.; Wang, T.; Li, Y. 2007. Isolating soil drought-induced genes from maize seedling leaves through suppression subtractive hybridization. Agricultural Sciences in China 6: 647-651.

Mittler, R. 2006. Abiotic stress, the field environment and stress combination. Trends in Plant Science 11: 15-19.

Monjardino, P.; Smith, A.G.; Jones, R.J. 2005. Heat stress effects on protein accumulation of maize endosperm. Crop Science 45: 1203-1210.

Ozturk, Z.N.; Talamé, V.; Deyholos, M.; Michalowski C.B.; Galbraith, D.W.; Gozukirmizi, N.; Tuberosa, R.; Bohnert, H.J. 2002. Monitoring large-scale changes in transcript abundance in drought- and saltstressed barley. Plant Molecular Biology 48: 551-573.
Persans, M.W.; Wang, J.; Schuler, M.A. 2001. Characterization of maize cytochrome P450 monooxygenases induced in response to safeners and bacterial pathogens. Plant Physiology 125: 1126-1138.

Praba, M.L.; Cairns, J.E.; Babu, R.C.; Lafitte, H.R. 2009. Identification of physiological traits underlying cultivar differences in drought tolerance in rice and wheat. Journal of Agronomy and Crop Science 195: 30-46.

Reymond, P.; Weber, H.; Damond, M.; Farmer, E. 2000. Differential gene expression in response to mechanical wounding and insect feeding in Arabidopsis. The Plant Cell 12: 707-719.

Rizhsky, L.; Liang, H.; Shuman, J.; Shulaev, V.; Davletova, S.; Mittler, R. 2004. When defense pathways collide. The response of Arabidopsis to a combination of drought and heat stress. Plant Physiology 134: 1683-1696.

Sachetto-Martins, G.L.; Franco, O.; de Oliveira, D.E. 2000. Plant glycinerich proteins: a family or just proteins with a common motif? Biochimica et Biophysica Acta 1492: 1-14.

Sharma, A.D.; Kaur, P. 2009. Combined effect of drought stress and heat shock on cyclophilin protein expression in Triticum aestivum. General and Applied Plant Physiology 35: 88-92.

Sheng, J.; D’Ovidlo, R.; Mehdy, M.C. 1991. Negative and positive regulation of a nove1 proline-rich protein mRNA byfungal elicitor and wounding. Plant Journal 1: 345-354.

Shi, C.; Thümmler, F.; Melchinger, A.E.; Wenzel, G.; Lübberstedt, T. 2005. Association between SCMV resistance and macroarray-based expression patterns in maize inbreds. Molecular Breeding 16: 173-184.

Talame, V.; Neslihan, Z.; Ozturk, H.; Bohnert, J.; Tuberosa, R. 2007. Barley transcripts profiles under dehydration shock and drought stress treatments: a comparative analysis. Journal of Experimental Botany 58: 229-240.

Vasak, M.; Hasler, D.W. 2000. Metallothioneins: new functional and structural insights. Current Opinion in Chemical Biology 4: 177183.

Wang, H.; Miyazaki, S.; Kawai, K.; Deyholos, M.; Galbraith, D.; Bohnert, H.J. 2003. Temporal progression of gene expression responses to salt shock in maize roots. Plant Molecular Biology 52: 873-891.

Yu, L.X.; Setter, T.L. 2003. Comparative transcriptional profiling of placenta and endosperm in developing maize kernels in response to water deficit. Plant Physiology 131: 568-582.

Zamani, A.; Sturrock, R.N.; Ekramoddoullah, A.K.M.; Liu, J.J.; Yu, X. 2004. Gene cloning and tissue expression analysis of a PR-5 thaumatin-like protein in Phellinus weirii-infected Douglas-fir. Phytopathology 94: 1235-1243.

Zhang, Y.; Fu, J.; Gu, R.; Wang, J.; Chen, X.; Jia, J.; Zhang, J.; Wang, G. 2009. Isolation and analysis of cold stress inducible genes in Zea mays by suppression substractive hybridization and cDNA macroarray. Plant Molecular Biology Reporter 27: 38-49.

Zheng, J.; Zhao, J.; Tao, Y.; Wang, J.; Liu, Y.; Fu, J.; Jin, Y.; Gao, P.; Zhang, J.; Bai, Y.; Wang, G. 2004. Isolation and analysis of water stress induced genes in maize seedlings by subtractive PCR and cDNA macroarray. Plant Molecular Biology 55: 807-823.

Zhuang, Y.L.; Ren, G.J.; Zhu, Y.; Hou, G.H.; Qu, X.; Li, Z.X.; Yue, G.D.; Zhang, J.R. 2008. Transcriptional profiles of immature ears and tassels in maize at early stage of water stress. Biologia Plantarum 52: 754-758.

Zhu, J.; Alvarez, S.; Marsh, E.L.; LeNoble, M.E.; Cho, I.J.; Sivaguru, M.; Chen, S.; Nguyen, H. T.; Wu, Y.; Schachtman, D. P.; Sharp, R. E. 2007. Cell Wall Proteome in the Maize Primary Root Elongation Zone. II. Region-Specific Changes in water soluble and lightly lonically bound proteins under water deficit. Plant Physiology 145: 1533-1544.

Zinselmeier, C.; Sun, Y.J.; Helentjaris, T.; Beatty, M.; Yang, S.; Smith, H.; Habben, J. 2002. The use of gene expression profiling to dissect the stress sensitivity of reproductive development in maize. Field Crops Research 75: 111-121.

Received December 11, 2009

Accepted September 28, 2010 